CHANGE IN CORPORALITY FUNCTIONS IN WOMEN WITH FYBROMIALGIA AND MULTIPLES SOMATICS AND FUNCTIONAL DISORDERS AFTER RECEIVED

\title{
SOMATODRAMATICAL THERAPY
}

J.P. Cornejo Diez De Medina ${ }^{1}$, A. vivero ${ }^{2}$, C. Valenzuela Hofsetter ${ }^{3}$, O.D. Robles Rivera ${ }^{4}$. Bersecio MV.

'Hospital Clinico Universidad De Chile, Unidad De Dolor, Santiago, Chile.

${ }^{3}$ Faculty of medicine Finis Terrae University, Medicine, Santiago, Chile.

INTRODUCTION: Dramatic techniques and somatodrama are rarely used in the treatment of those patients. Major failures have been described in the different functions of corporeality in women suffering from fibromyalgia

OBJECTIVES: Demonstrate the plausibility of using these techniques in individual treatment. Demonstrate changes in different functions of corporality caused by effect somatodramathical therapy in women with fibromyalgia

METHODOLOGY: Case Study / Control; Quanti and Quali Analysis; Initial evaluation with multiple scales; Evaluated variables: Alexithymia, personality traits, depressive and anxious symptoms, functionality, corporality, anhedonia, somatic functionality-scale, OPD2 Interview using corporal accessory axis. Three interviewers. Consensus analysis.

\section{OPD2-corporality Damaged functions}

Self-regulation of corporal-self; Tolerance to relative affections of the body, selfsteem regulation in relation to one's own body. inner body Communication, empathy with another's corporal state. Body in the framework of internalexternal objects attachment, establish affectionate corporal contact, receive and provide corporal support.

Damaged functions in structural module: Self-destructive and self-devaluative tendencies. Over and loss regulation of self-steem. Difficulties in regulation of affections and the body; to express one's own affections; to be touched by other people's affections; to take distance and regulate them from one's own affections; to separate from others.

\section{All functions improve at $6 \mathrm{~m}$ in qualitative analyses}

Alexithymia and corporal changes in OPD2 at $6 \mathrm{~m}$ present improvement only in the $A G$ at $6 \mathrm{~m} \mathrm{ss} p(<0.05)$. Difference is maintained at $12 \mathrm{~m}$.

CONCLUSION: We hypothesize that somatodrama in those patients would produce psychic changes and functional networks, improving the interhemispheric interconnectivity specially brain hemispheric functions and improve mind-body functions for at least 12 months. 